\title{
In vitro effect of substrate, temperature and photoperiod on Phakopsora pachyrhizi urediniospore germination and germ tube growth
}

\author{
Marta Maria Casa Blum¹; Erlei Melo Reis ${ }^{2,3}$, Francieli Tavares Vieira ${ }^{2}$, Rita Carlini ${ }^{2}$
}

\begin{abstract}
${ }^{1}$ Universidade do Alto Uruguai, Erechim, RS, Brazil; ${ }^{2}$ Faculdade de Agronomia e Medicina Veterinária, Universidade de Passo Fundo, Passo Fundo, RS - Brazil; ${ }^{3}$ Endereço atual: OR Melhoramento de Sementes Ltda, Passo Fundo, RS, Brazil.

Autor para correspondência: Erlei Melo Reis (erleireis@upf.br)

Data de chegada: 16/04/2014. Aceito para publicação em: 03/03/2015.
\end{abstract}

$10.1590 / 0100-5405 / 1999$

\begin{abstract}
Blum, M.M.C.; Reis, E. M.; Franciei, T.V., Carlini, R. In vitro effect of substrate, temperature and photoperiod on Phakopsora pachyrhizi urediniospore germination and germ tube growth. Summa Phytopathologica, v.41, n.2, p.101-106, 2015.

In vitro experiments were conducted to assess the effects of substrate, temperature and time of exposure to temperature and photoperiod on $P$. pachyrhizi uredospore germination and germ tube growth. The following substrates were tested: water-agar and soybean leaf extract-agar at different leaf concentrations $(0.5,1.0,2.0$ and $4.0 \mathrm{~g}$ of leaves and $15 \mathrm{~g}$ agar $/ \mathrm{L}$ water $)$, temperatures $\left(10,15,20,25,30\right.$, and $\left.35^{\circ} \mathrm{C}\right)$ and times of exposure $(1,2,3$, $4,5,6,7$, and 8 hours) to temperature and 12 different photoperiods. The highest germination and germ tube length was found for the soybean leaf

extract agar. Maximum P. pachyrhizi uredospore germination was obtained at 21.8 and $22.3^{\circ} \mathrm{C}$, and maximum germ tube growth at 21.4 and $22.1^{\circ} \mathrm{C}$. The maximum uredospore germination was found at 6.4 hours exposure, while the maximum germ tube length was obtained at $7.7 \mathrm{~h}$ exposure. Regarding photoperiod, the maximum spore germination and the maximum uredospore germ tube length were found in the dark. Neither spore germination nor uredospore germ tube growth was completely inhibited by the exposure to continuous light.
\end{abstract}

Additional keywords: mushroom, anthracnose, bacterial spot, sorghum, passion fruit

\section{RESUMO}

Blum, M.M.C.; Reis, E. M.; Franciei, T.V., Carlini, R. In vitro efeito de substratos, temperatura e fotoperíodo na germinação e crescimento do tubo germinativo de uredosporos de Phakopsora pachyrhizi. Summa Phytopathologica, v.41, n.2, p.101-106, 2015.

Em experimentos conduzido in vitro, foi quantificado os efeitos de substatos, temperatura, tempo de exposição e fotoperíodo na germinação e no comprimento do turbos germinativo de uredosporos de Pakopsora pachyrhizi. Os substratos testados foram água-ágar e estrato de folhas soja-ágar $(0.5,1.0$, 2.0 e $4.0 \mathrm{~g}$ de estratos foliar e $5 \mathrm{~g}$ de ágar/L de água), temperaturas $(10,15$, $20,25,30$, e $350 \mathrm{oC})$, tempos de exposição $(1,2,3,4,5,6,7$, e 8 hours $)$ e 12 distintos fotoperiodos. A maior germinação e comprimento do tubo germinativo foi obtido a 21,8 e $22,3^{\circ} \mathrm{C}$ e o máximo crescimento dos tubos a 21,4 e $22.1^{\circ} \mathrm{C}$. TA máxima germinação dos esporos foi obtida com 6.4 horas de exposição e o comprimento dos tubos germinativo com $7.7 \mathrm{~h}$ de exposição. Tanto a máxima germinação com o máximo crescimento dos tubos de germinação ocorreram no escuro. Tanto a germinação dos uredosporos como o crescimento do tubo germinativo não foram completamente inibidos pela exposição à luz contínua.

Palavras-chave adicionais: ambiente, ferrugem da soja, germinação de esporos.

Phakopsora pachyrhizi Syd. \& Syd. (Pp), the causal agent of Asian soybean rust, is a biotrophic fungus that does not develop in synthetic culture media. Its urediniospores can be maintained and/or multiplied by means of successive inoculations in soybean plants. Its maintenance can also be accomplished in kudzu (Pueraria lobata Willd.) and perennial soybean [Neonotonia wightii (Wight \& Arn.) Lackey], which are $P p$ secondary hosts found in southern Brazil (14).

In vitro evaluation of the sensitivity of this fungus to a chemical, using artificial substrate, has been described in the literature, especially for necrotrophic fungi, which can normally have the mycelium growth measured under different fungicide concentrations. However, this methodology has limitation for biotrophic fungi, which can only be evaluated based on spore germination or on germ tube length (16).

For both necrotrophic and biotrophic parasites, determination of the in vitro sensitivity of a fungus to a fungicide requires the identification of different factors such as substrates, temperature for fungal growth, photoperiod and exposure time to a particular environment, which promotes the highest rate of spore germination, and the maximum germ tube growth in the shortest time.

The aim of this study was to select substrate, temperature, exposure time and photoperiod to promote the maximum germination and germ tube growth of $P$. pachyrhizi urediniospores.

\section{MATERIAL AND METHODS}

In vitro experiments were conducted in the Laboratory of Plant Pathology (Mycology), Faculty of Agronomy and Veterinary Medicine, University of Passo Fundo - UPF (Passo Fundo / RS)(FAMV-UPF), in 2006 and 2007. 
Soybean rust inoculum was composed of a populational urediniospore sample collected from naturally infected plants in the 2004/05 growing season, in the experimental field of FAMV-UPF, and maintained and multiplied through repeated inoculation in soybean plants (cultivar 'BRS 154') under a partially controlled environment $\left(22 \pm 2^{\circ} \mathrm{C}\right.$ and $14 \mathrm{~h}$ photoperiod).

Substrates for $\boldsymbol{P}$. pachyrhizi uredospore germination. Five substrates were employed: agar-water (1,000 $\mathrm{mL}$ of water, $14 \mathrm{~g}$ agar), $0.5 \mathrm{~g}$ soybean leaf extract agar $(0.5 \mathrm{~g}$ leaf ground in a blender $+1,000$ $\mathrm{ml}$ of water and $14 \mathrm{~g}$ agar), $1 \mathrm{~g}$ leaf extract + agar, $2 \mathrm{~g}$ leaf extract agar, and $4 \mathrm{~g}$ leaf extract agar. The leaves of soybean cultivar 'Codetec' 214 RR, 25 days old, were collected from plants cultivated in a growth chamber without having received any chemical application.

The experimental unit consisted of a plastic Petri dish, $6.0 \mathrm{~cm}$ diameter, and four replicates in a randomized complete block design.

Urediniospores were suspended and diluted in distilled water, yielding a concentration of 2,000 spores $/ \mathrm{mL}$. Sterile and disposable plastic Petri dishes $(60 \times 15 \mathrm{~mm})$ were used, and one $\mathrm{mL}$ of a uredospore suspension ( $2 \times 10^{3}$ urediniospores per plate) was dispensed on the substrates. The latter were autoclaved and poured into dishes at $24 \mathrm{~h}$ before spore suspension deposition. Petri dishes were kept in incubators (BOD - Biological Oxygen Demand) under conditions of controlled temperature $\left(25^{\circ} \mathrm{C}\right), 12 \mathrm{~h}$ photoperiod and continuous light provided by two fluorescent lamps (OSRAM, Universal 40 w, Light Special Day, Brazil K.798.B.6) at $35 \mathrm{~cm}$ from the dish surface.

Urediniospore germination and germ tube length were evaluated by scanning the plate under an optical microscope and examining 100 spores per replicate. The uredospore showing a germ tube longer than its largest diameter was considered germinated (19). Germ tube length was measured by using a micrometer adapted to the eyepiece of the microscope and calibrated with a micrometer Zeiss West Germany (5 $+100 / 100 \mu \mathrm{m})$.

After the time set for each experiment, germination and germ tube growth were stopped by adding $0.3 \mathrm{~mL}$ of acetone solution $(100 \%)$ and cotton blue dye to each Petri dish. Then, the plates were kept in a refrigerator $\left(4^{\circ} \mathrm{C}\right)$ for further evaluation.

All tests were conducted twice (Experiments 1 and 2), except the ones performed to select substrate, which were carried out three times (Experiments 1, 2 and 3).

Data were expressed as a percentage of urediniospore germination and germ tube length $(\mu \mathrm{m})$ and subjected to analysis of variance, while means were compared according to Tukey's test $(p=0.05)$.

Temperature on $\boldsymbol{P}$. pachyrhizi urediniospore germination and germ tube growth. The temperatures $0,15,20,25,30$ and $35^{\circ} \mathrm{C}$ were tested. A suspension of $P$. pachyrhizi urediniospores was poured into water-agar and incubated at each temperature in continuous darkness for six hours.

Data were subjected to analysis of variance and, when significant, to quadratic regression analysis to describe the effect of temperature on urediniospore germination and germ tube length. The optimum temperature was determined by calculating the curve maximum point. Experiments were repeated twice.

Exposure time on $P$. pachyrhizi maximal urediniospore germination and germ tube growth. Exposure times of 1, 2, 3, 4, 5, 6, 7 and $8 \mathrm{~h}$ were assessed for spore germination. The urediniospore suspension was poured into water-agar substrate and kept under continuous darkness at $22^{\circ} \mathrm{C}$ during different exposure times. Once the exposure times for the germination test were completed, four dishes per replicate were removed from the incubation chamber and the germination and germ tube growth stopped.
Data were subjected to analysis of variance and, when significant, to quadratic regression analysis to describe the effect of exposure time on urediniospore germination and germ tube length. The optimum exposure time was determined by calculating the curve maximum point. Experiments were repeated twice.

P. pachyrhizi urediniospore germination and germ tube growth under different photoperiods. Artificial light was provided by four fluorescent lamps (Philips TL-D 15W/75-650), at $10 \mathrm{~cm}$ from the plates, in an incubator. The light during incubation was continuous; thus, dark was provided by packing each Petri dish with two layers of aluminum foil. Light intensity was 500 lux, determined by using a luximeter Extech Instruments, model HD 400.

Twelve treatments were evaluated and defined by a gradual increase in exposure to light over dark and light against the dark, as follows: 1 $\mathrm{h}$ dark followed by $5 \mathrm{~h}$ light, $2 \mathrm{~h}$ dark followed by $4 \mathrm{~h}$ light: $3 \mathrm{~h}$ dark followed by $3 \mathrm{~h}$ light, $4 \mathrm{~h}$ dark followed by $2 \mathrm{~h}$ light: $5 \mathrm{~h}$ dark followed by $1 \mathrm{~h}$ light: $6 \mathrm{~h}$ dark, $1 \mathrm{~h}$ light followed by $5 \mathrm{~h}$ dark, $2 \mathrm{~h}$ light followed by $4 \mathrm{~h}$ dark, $3 \mathrm{~h}$ light followed by $3 \mathrm{~h}$ dark, $4 \mathrm{~h}$ light followed by $2 \mathrm{~h}$ dark, $5 \mathrm{~h}$ light followed by $1 \mathrm{~h}$ dark and $6 \mathrm{~h}$ continuous light.

The urediniospore suspension was poured into water-agar substrate and kept at $22^{\circ} \mathrm{C}$ for 6 hours in the different photoperiods.

Experiments were conducted according to a complete randomized block design with four replicates. Data were subjected to analysis of variance and means compared according to Tukey's multiple range test at $p=5 \%$.

\section{RESULTS}

Uredospore germination was increased by the substrate. The lowest germination ( $83.2 \%$ ) was obtained with $0.5 \mathrm{~g}$ soybean leaf extract (Table 1). In water-agar, $0.5 \mathrm{~g} / \mathrm{L}$ and $1.0 \mathrm{~g} / \mathrm{L}$ soybean leaf extract showed no difference. Culture media containing $1 \mathrm{~g}$ and $2 \mathrm{~g}$ of leaf extract were also similar. The highest germination (96.5\%) was obtained with $4 \mathrm{~g}$ of leaf extract; however, this result did not differ significantly from that found with $2 \mathrm{~g}$ of leaf extract agar (Table 1).

Regarding the effect of substrates on germ tube growth, the greatest growth $(32.7 \mu \mathrm{m})$ was found for the medium containing $1.0 \mathrm{~g}$ of leaf extract, but it was not significantly different from the other treatments (Table 1).

Temperature effect on spore germination and germ tube growth. In the two experiments (Figs. 1 and 2), polynomial regression analysis showed a significant effect on P. pachyrhizi spore germination and germ tube growth. The maximum germination of $P$. pachyrhizi uredospores, estimated by the models, was found at $21.8^{\circ} \mathrm{C}$ and $22.3^{\circ} \mathrm{C}$ for the first and the second experiment, respectively (Fig. 1).

Maximum spore germ tube length was obtained at $21.4^{\circ} \mathrm{C}$ and $22.1^{\circ} \mathrm{C}$ for the first and second experiment, respectively (Fig. 2).

The optimal temperature estimated for $P$. pachyrhizi spore germination was $21.8^{\circ} \mathrm{C}$ for the first experiment and $22.3^{\circ} \mathrm{C}$ for the second one. The optimal temperature for germ tube growth was $21.4^{\circ} \mathrm{C}$ for the first experiment and $22.1^{\circ} \mathrm{C}$ for the second one (Figs. 1 and 2).

The tested cardinal temperatures were not sufficient to completely inhibit P. pachyrhizi urediniospore germination and/or germ tube growth.

Exposure time on spore germination and germ tube growth. The curves for the relationship between urediniospore germination and exposure times from four to 40 hours (first trial) were not significant. The exposure times in the second trial (one to eight hours) showed that the $6.4 \mathrm{~h}$ time in both experiments resulted in the maximum spore 
Table 1. Germination (\%) and germ tube length of Phakopsora pachyrhizi uredospores on several substrates incubated for 12 hours at $25^{\circ} \mathrm{C}$ in the dark

\begin{tabular}{lcccc}
\hline \multicolumn{1}{c}{ Substrate } & \multicolumn{3}{c}{ Mean $(\%)$} & Length $(\mu \mathrm{m})$ \\
\hline Soybean leaf extract- agar & $4.0 \mathrm{~g} / \mathrm{L}$ & 96.5 & $\mathrm{a}$ & $24.7 \mathrm{n} . \mathrm{s}$. \\
Soybean leaf extract-gar & $2.0 \mathrm{~g} / \mathrm{L}$ & 93.7 & $\mathrm{ab}$ & 19.1 \\
Soybean leaf extract-agar & $1.0 \mathrm{~g} / \mathrm{L}$ & 88.0 & $\mathrm{bc}$ & 32.7 \\
Water-agar & $15.0 \mathrm{~g} / \mathrm{L}$ & 84.5 & $\mathrm{c}$ & 24.3 \\
Soybean leaf extract-agar & $0.5 \mathrm{~g} / \mathrm{L}$ & 83.2 & $\mathrm{c}$ & 17.8 \\
\hline C.V.(\%) & & 4.2 & & 35.9 \\
\hline
\end{tabular}

Means followed by the same letter in the column do not significantly differ according to Tukey's test at $\mathrm{p}=0.05$.
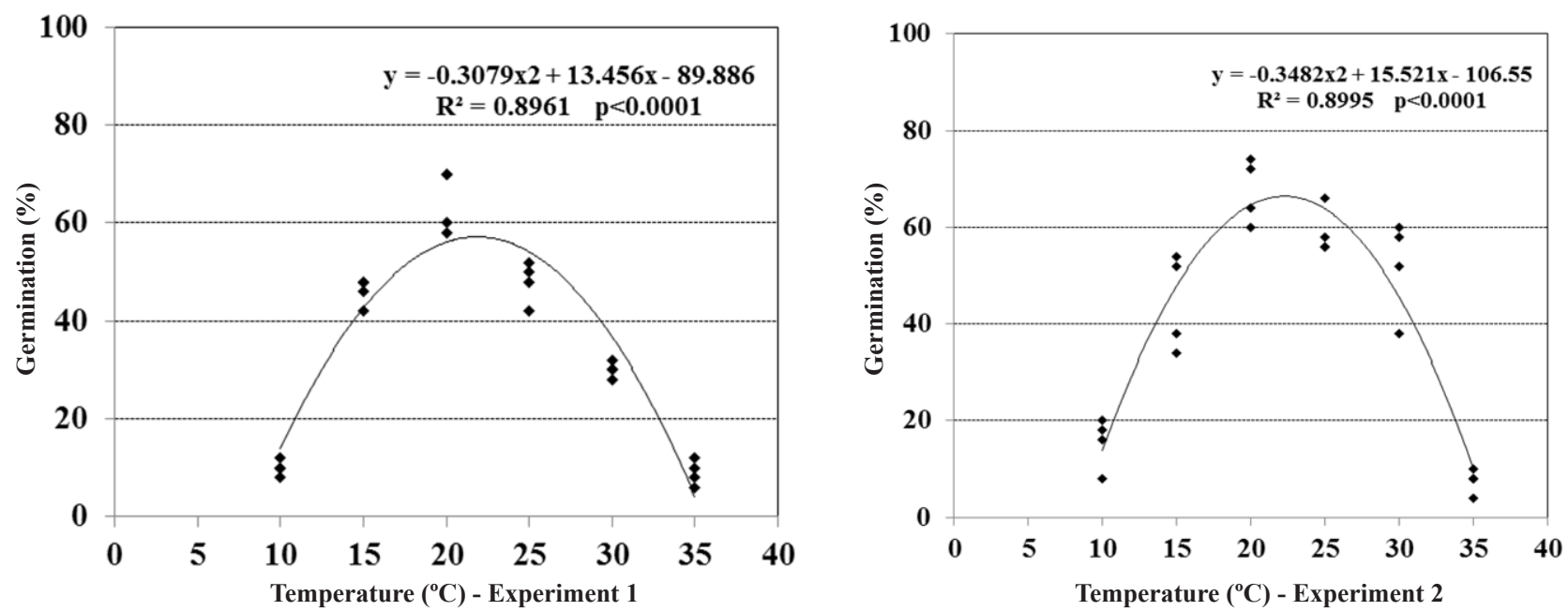

Figure 1. Effect of temperature on the germination of Phakopsora pachyrhizi uredospores. Experiment 1, optimal temperature $21.8^{\circ} \mathrm{C}$; Experiment $2,22 \cdot 3^{\circ} \mathrm{C}$. Exposure time of $6 \mathrm{~h}$ in the dark.
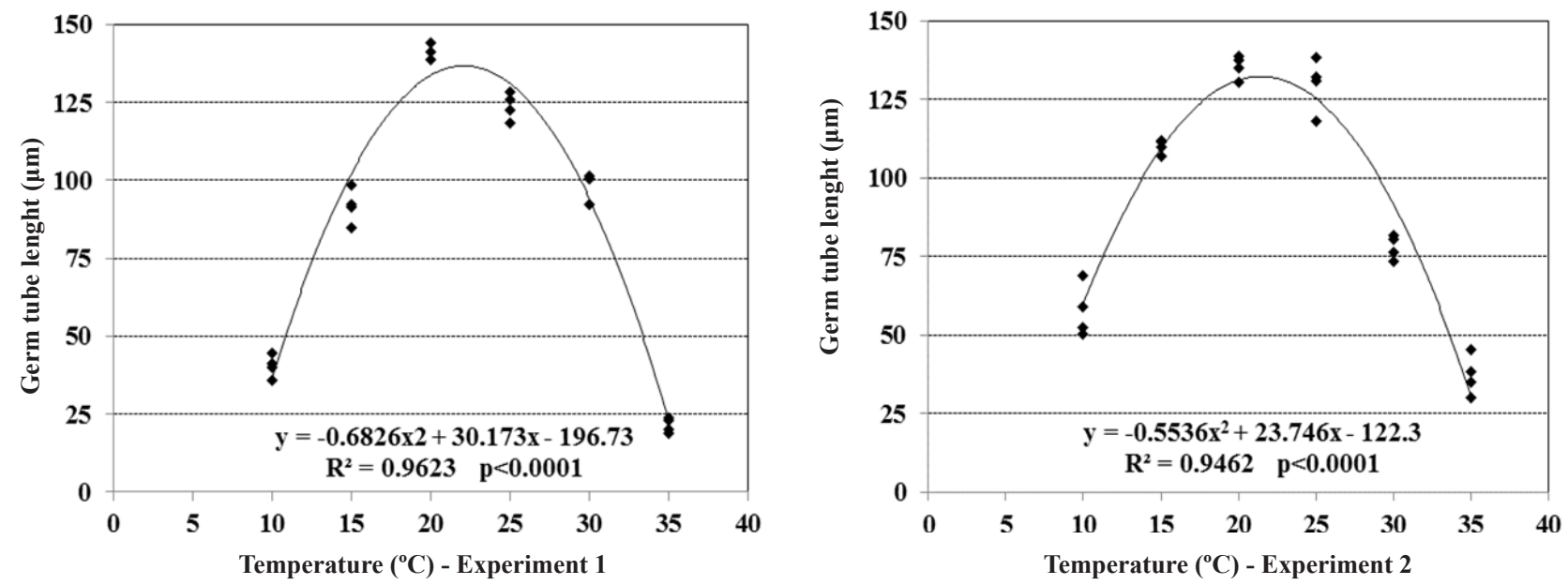

Figure 2. Effect of temperature on the germ tube length of Phakopsora pachyrhizi uredospores. Experiment 1, optimal temperature, $21.4^{\circ} \mathrm{C}$; Experiment $2,22.1^{\circ} \mathrm{C}$. Exposure time of $6 \mathrm{~h}$ in the dark.

germination (Fig. 3).

The maximum germ tube length, under exposure time of up to 40 hours, for the two experiments, occurred at $37.7 \mathrm{~h}$ (Fig. 3), when length was estimated at $653 \mu \mathrm{m}$ and $637 \mu \mathrm{m}$, respectively (Fig. 4). For the eight-hour exposure time, germ tube growth was linear, and for each exposure hour an increase of 44.3 and $45.2 \mu \mathrm{m}$ was quantified (Figure
4), while the maximum growth at eight hours was 354 and $361.4 \mu \mathrm{m}$ for the two experiments, respectively (Fig. 4). Spore germination and germ tube growth started within one hour exposure. Maximum germination occurred at $6.4 \mathrm{~h}$ exposure. For the $8 \mathrm{~h}$ exposure time (Fig. 4), polynomial regression analysis showed a significant effect on spore germination and linear regression showed the same effect 

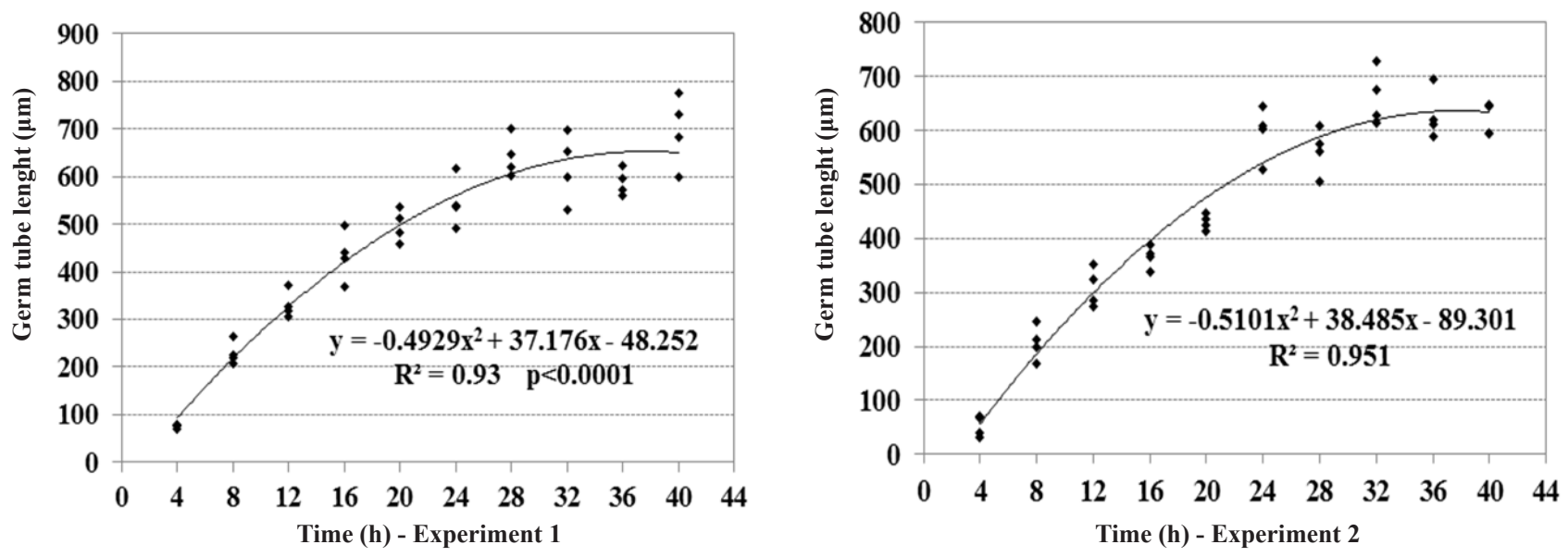

Figure 3. Effect of exposure time on the germ tube length of Phakopsora pachyrhizi uredospores at $22^{\circ} \mathrm{C}$, in the dark. Experiment 1 , optimal time 1, $37.7 \mathrm{~h}$; Experiment 2, 37.7h. Exposure time of 4 to $40 \mathrm{~h}$ in the dark.
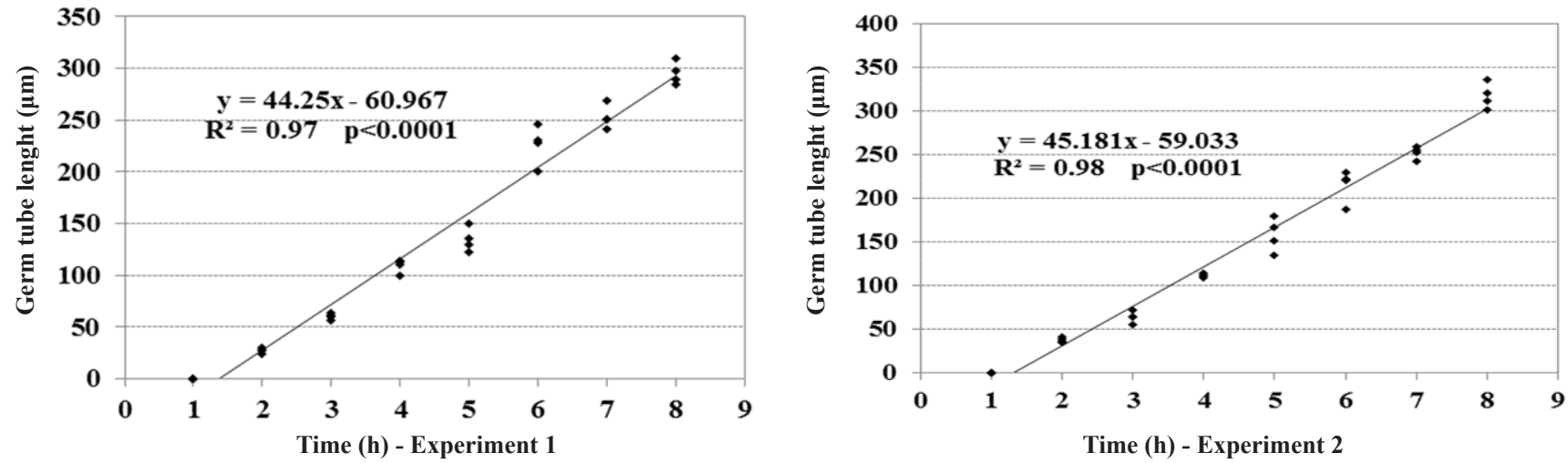

Figure 4. Effect of exposure time on the germ tube length of Phakopsora pachyrhizi uredospores at $22^{\circ} \mathrm{C}$. Experiment 1 , maximum length, 354 $\mu \mathrm{m}$; Experiment 2, $361 \mu \mathrm{m}$. Exposure time of 8 hours in the dark.

on germ tube length. Considering four to $40 \mathrm{~h}$ exposure time (Fig. 3), polynomial regression analysis showed a significant effect on $P$. pachyrhizi germ tube length.

Photoperiod effect on spore germination and germ tube growth. Regarding the effect of photoperiod on P. pachyrhizi spore germination, the dark promoted the highest percentage of germination. Under continuous light and $1 \mathrm{~h}$ dark, followed by $5 \mathrm{~h}$ light, the lowest germination was found, showing $83.9 \%$ reduction. In experiment 2 , the greatest reduction in germination was obtained after $1 \mathrm{~h}$ dark followed by $5 \mathrm{~h}$ light, yielding $71.8 \%$ germination (Fig. 5).

Under twelve different light regimes, the fastest growth occurred under darkness. There was no difference for the darkness combinations from $4 \mathrm{~h}$ dark followed by $2 \mathrm{~h}$ light; $5 \mathrm{~h}$ dark followed by $1 \mathrm{~h}$ light and $1 \mathrm{~h}$ light followed by $5 \mathrm{~h}$ dark, providing the longest germ tube growth (Fig. 6).

The greatest inhibition in P. pachyrhizi germ tube growth was under $1 \mathrm{~h}$ dark followed by $5 \mathrm{~h}$ light $(71.1 \%$ inhibition in experiment 1) and under continuous light (53.4\% in experiment 2). Maximum germination and germ tube length were observed under darkness. Exposure to continuous light did not totally inhibit $P$. pachyrhizi germ tube growth (Fig. 6).

\section{DISCUSSION}

\section{Substrate}

Stadnik et al. (17) evaluated different substrates on the germination of Puccinia graminis Pers urediniospores and obtained the highest germination for dextrose $2 \%$ and chitosan $100 \mathrm{mg} / \mathrm{L}$ solution. Germination and germ tube length for P. pachyrhizi reduced when the substrate $100 \%$ potato dextrose agar (PDA) was used for in vitro tests.

Leaf extract agar. Reis and Richter (13) studied the effect of nine different substrates on Puccinia triticina Eriks spore germination and germ tube length, including water-agar, potato-sucrose agar $(25 \%$ and $100 \%$ ) and wheat leaf extract-agar. They showed that substrates based on leaf extracts and infusion promoted higher spore germination, compared to the standard water-agar substrate. These results are similar to our findings.

Water-agar. This is the most used substrate for fungal spore germination studies.

The water-agar substrate has often been used by several authors $(2,3,4,5,6,7,8,9,18$, and 20).

Kochman and Brown (9) observed higher rates of spore germination for Puccinia graminis avenae Erikss. \& Henn. and Puccinia coronata 


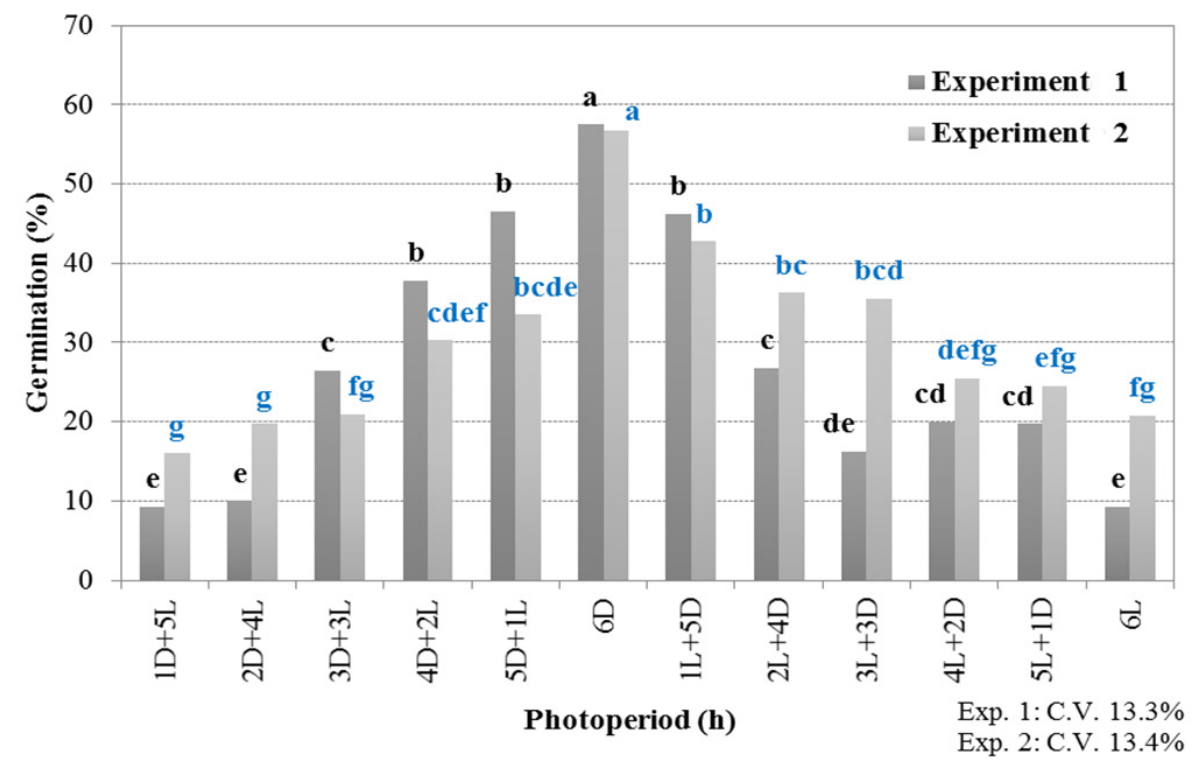

Figure 5. Effect of photoperiod on the germination of Phakopsora pachyrhizi uredospores at $22^{\circ} \mathrm{C} . \mathrm{D}=\mathrm{dark} ; \mathrm{L}=$ light.

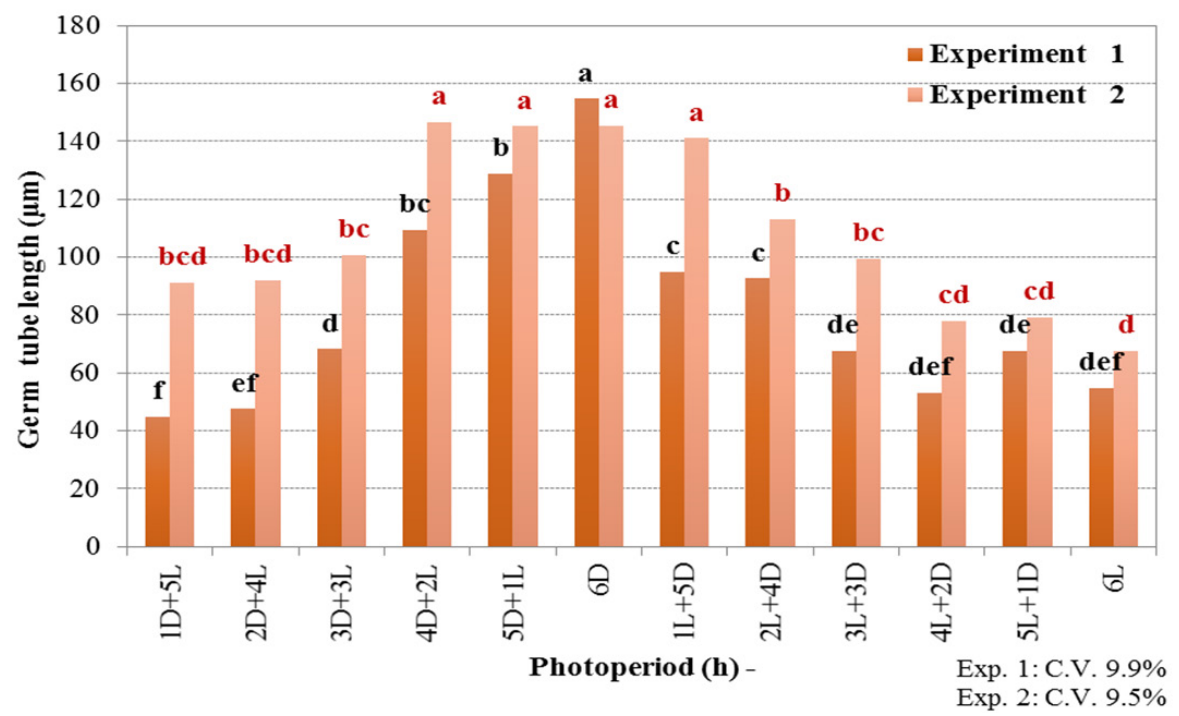

Figure 6. Effect of photoperiod on the germ tube length of Phakopsora pachyrhizi uredospores at $22^{\circ} \mathrm{C} . \mathrm{D}=\mathrm{dark} ; \mathrm{L}=$ light.

avenae Fraser \& Led. by using the substrate water-agar in vitro, compared to germination on oat leaves.

Russell (15) described an in vitro methodology to test fungal spore sensitivity to fungicides and suggested the use of artificial substrates to test spore viability. These can range from nutrient-rich media such as PDA, malt extract and agar-deficient substrates like water-agar. However, that author emphasized that sensitivity values may vary depending on the used material and reinforced that different sensitivity results to fungicides can be obtained due to the use of different host varieties and different phenological stages during in vivo sensitivity tests.

The data reported by Russell (15) and the present results for the substrates tested on $P$. pachyrhizi spore germination indicate that the water-agar substrate is a good option for in vitro tests.

Temperature. Marchetti et al. (10) reported a temperature range between 15 and $25^{\circ} \mathrm{C}$ for P. pachyrhizi germination. Godoy and Flausino (7) found a temperature range between 18 and $26^{\circ} \mathrm{C}$. Alves et al. (1), using a relationship function between germination and temperature, identified a germination range between 15 and $25^{\circ} \mathrm{C}$ for $P$. pachyrhizi. Bonde et al. (3) evaluated different isolates and obtained the maximum spore germination in the temperature range between 21.8 and $23.4^{\circ} \mathrm{C}$, while for germ tube growth the range was between 21.0 and $24.4^{\circ} \mathrm{C}$. Our results confirmed those previously reported data. However, we calculated the optimal temperature by means of regression, while other researchers have mentioned a temperature range.

Effect of light. Both the presence and the absence of light from the first exposure moment showed similar trends considering $P$. pachyrhizi germination reduction or increase and germ tube growth.

Bonde et al. (2) observed P. pachyrhizi germination and appressorium formation on inoculated soybean leaflets at different incubation times (five to 16 hours), all in the absence of light. Piza et al. (12) evaluated the effect of light on spore germination for Puccinia psidii Winter, under continuous light, continuous darkness and 8, 16 and $20 \mathrm{~h}$ photoperiod, and obtained the highest germination under 
continuous darkness and the lowest germination under continuous light. Naruzawa et al. (11) evaluated the effect of light (light and dark) and temperature $\left(5,10.15,2025,3035\right.$ and $\left.40^{\circ} \mathrm{C}\right)$ on the germination of P. euvitis Ono and observed that absence of light provided the greatest germination to the temperature of $25^{\circ} \mathrm{C}$, while the light or dark regime was indifferent to higher temperatures.

Furtado (4) reported that in experiments conducted in vitro in the absence of light there was great spore germination and appressorium formation for P. pachyrhizi.

The results obtained in our experiments confirm those obtained by Marchetti et al. (10).

Furthermore, Bonde et al. (2) reported early germination of $P$. pachyrhizi between one and two hours after the inoculation of plants (incubation in a mist chamber, $20^{\circ} \mathrm{C}$, in the dark).

Alves et al. (1) evaluated in vitro the effect of temperature and wetness duration on the germination of $P$. pachyrhizi, under the incubation periods of one, two, four, eight and 12 hours. They identified the minimum period of one hour for the start of germination and stabilization of the process from eight hours, partly confirming the results obtained for exposure time in this experiment.

Bonde et al. (2), evaluating the effect of temperature on P. pachyrhizi germination and germ tube length in vitro, tested two incubation periods (three and six hours) and found no differences between exposure times in relation to the identified temperatures.

\section{REFERENCES}

1. Alves, S. A. M.; Furtado, G. Q.; Bergamin Filho, A. Influência das condições climáticas sobre a ferrugem da soja. In: Zambolin, L. (Ed.). Ferrugem asiática da soja. UFV, DFP, Viçosa, MG, 140 p. 2006.

2. Bonde, M. R.; Melching, J. S.; Bromfield, K. R. Histology of the suscept-pathogen relationship between Glycine max and Phakopsora pachyrhizi, the case of soybean rust. Phytopathology, St Paul, v. 66, p.1290-1294. 1976.

3. Bonde, M. R.; Berner, D. K.; Nester, S. E.; Frederick, R. D. (2007) Effects of temperature on urediniospore germination, germ tube growth, and initiation of infection in soybean by Phakopsora isolates. Phytopathology, St Paul, v. 97, p. 997-1003. 2007.

4. Furtado, G. Q. Ferrugem asiática da soja: métodos de preservação dos urediniósporos e fatores relacionados à infecção do hospedeiro. 2007. Tese (Doutorado em Fitopatologia) - Escola Superior de Agricultura Luiz de Queiroz (ESALQ), Piracicaba

5. Furtado, G. Q.; Alves, S. A. M.; Czermainski, A. B. C.; Mossola, Jr N.
S. Preservação dos urediniosporos de Phakopsora pachyrhizi. Summa Phytopathologica, Botucatu 31 (Supl.):79. 2005.

6. Garcia, E. O.; Casagrande, M. V.; Rago, A. M.; Mossola, Jr N. S. Preservação de urediniósporos de Puccinia melanocephala, agente causal de ferrugem em cana-de-açúcar. Summa Phytopathologica, Botucatu, v. 33, p.152-156. 2007.

7. Godoy, C. V.; Flausino, A. M.. Efeito da temperatura na germinação de uredosporos de Phakopsora pachyrhizi, viabilidade e sobrevivência em diferentes condições de armazenamento. Fitopatologia Brasileira, Brasília, DF, 29 (Supl.):124.2004.

8. Kochman, J. K. The effect of temperature on development of soybean rust (Phakopsora pachyrhizi). Australian Journal of Agricultural Research, Clayton, v. 30, p. 273-277. 1979.

9. Kochman, J. K.; Brown, J. F. Effect of temperature, light and host on prepenetration development of Puccinia graminis avenae and Puccinia coronata avenae. Annals of Applied Biology, Warwick, v. 82, p. 241-249. 2008.

10. Marchetti, M. A.; Melching, J. S.; Bromfield, K. R. The effects of temperature and dew period on germination and infection by urediospores of Phakopsora pachyrhizi. Phytopathology, St. Paul, v. 66, p. 461-463. 1976.

11. Naruzawa, E. S.; Celoto, M. I. B.; Papa, M. F. S.; Tomquelski, G. V.; Boliani, A. C. Estudos epidemiológicos e controle químico de Phakopsora euvitis. Fitopatologia Brasileira, Brasília, DF, v. 31, p. 41-45.2006.

12. Piza, S. M. T.; Ribeiro, I. J. A. Influência da luz e da temperatura na germinação de uredosporos de Puccinia psidii. Bragantia, São Paulo, v. 47, p. 75-78. 1988.

13. Reis, E. M.; Richter, R. L. Efeito de substratos sobre a germinação de uredosporos e comprimento de tubos germinativos de Puccinia triticina. Fitopatologia Brasileira, Brasília, DF, v. 32, p.75-78. 2007.

14. Reis, E. M.; Scheer, O.; Rovedor, J. Kudzú (Pueraria lobata) hospedeiro secundário de Phakopsora pachyrhizi, no Brasil. Fitopatologia Brasileira, Brasília, DF, 30 (Suplemento): 130. 2005.

15 Russel, P. E. Sensitivity baselines in fungicide resistance research and management. FRAC Monograph ${ }^{\circ}$ 3, Cambridge CB2 5AN, UK. 2004.

16. Silva, C.; Souza, J. A. Sensibilidade in vitro de Phakopsora pachyrhizi a alguns fungicidas. Summa Phytopathologica, Botucatu, 31(Supl.) 79. 2005.

17. Stadinic, M. J.; Elgueddari, N. E.; Moerschbacher, B. M. Efeito do extrato de Ulva fasciata e da quitosana na germinação de uredóporos de Puccinia graminis e na atividade de peroxidade em trigo. Summa Phytopathologica, Botucatu, 31 (Supl.) 24. 2005.

18. Tessmann, D.; Dianese, J. C. Hentriacontane: a leaf hydrocarbon from Syzygium jambos with stimulatory effects on the germination of urediniospores of Puccinia psidii. Fitopatologia Brasileira, Brasília, DF, v. 27, p.538-542. 2002.

19. Zadoks, J. C. \& Schein, R .D. Epidemiology and plant disease management. New York Oxford University Press, 1979. 427p.

20. Zambenedetti, E. B.; Alves, E.; Pozza, E. A.; Araújo, D. V. Germinação de urediniósporos de Phakopsora pachyrhizi em diferentes métodos de armazenamento. Summa Phytopathologica, Botucatu, v. 33, p.83-85. 2007. 